\title{
RADIOCARBON DATING IN NEAR-EASTERN CONTEXTS: CONFUSION AND QUALITY CONTROL
}

\author{
Johannes van der Plicht ${ }^{1} \bullet$ Hendrik J Bruins ${ }^{2}$
}

\begin{abstract}
Near-Eastern archaeology has long remained oblivious to radiocarbon dating as unique historical calendars brought about a perception that ${ }^{14} \mathrm{C}$ dating is superfluous. Circular chronological reasoning may occur as a result. There is now strong ${ }^{14} \mathrm{C}$ evidence that the early part of Egyptian history seems older than age assessments currently in vogue among scholars. It is vital to apply systematic and high-quality ${ }^{14} \mathrm{C}$ dating to each and every excavation in the Near East to measure time with the same yardstick. Such a strategy will enable chronological comparison of different areas at an excavation site and also between sites and regions, independent of cultural deliberations. This is essential for proper interpretation of archaeological layers and association with data from other fields. Radiocarbon $\left({ }^{14} \mathrm{C}\right)$ is the most common radiometric dating tool applied in archaeology, geosciences, and environmental research. Stringent quality control is required to build up a reliable ${ }^{14} \mathrm{C}$ chronology for the historical periods in Near-Eastern contexts. Important aspects of quality control involve regular laboratory intercomparisons, transparent duplicate and triplicate analysis of selected samples, conventional versus accelerator mass spectrometry (AMS) (i.e. sample size), sample selection and association. Finally, bones may provide short-lived dates in important stratigraphic archaeological contexts.
\end{abstract}

\section{INTRODUCTION}

Does radiocarbon dating make sense for those periods of the ancient Near East in which archaeological strata and finds are linked with the unique historical calendars of Egypt and Mesopotamia, or later historical periods? Initially, many archaeologists working in the region answered this question negatively, considering the method too crude as compared to archaeological age assessment. Even today considerable confusion is encountered about the merits and applicability of ${ }^{14} \mathrm{C}$ dating in Near-Eastern contexts.

It must be stated clearly that both historical calendars and ${ }^{14} \mathrm{C}$ dating have their own unique assets and limitations. "A scholarly attitude towards ${ }^{14} \mathrm{C}$ dating as a mere indication of probability not to be taken seriously, is as unhelpful in the search of past reality as scientific derision of archaeo-historical dating is merely subjective interpretation of layers and antiquities with no semblance of probability" (Bruins and Mook 1989).

Each year many thousands of dates are produced worldwide by more than a hundred ${ }^{14} \mathrm{C}$ laboratories. Large samples, on the order of grams of carbon, can be measured by conventional techniques: proportional gas counting and liquid scintillation spectrometry. Small samples, on the order of milligrams of carbon, can be dated by accelerator mass spectrometry (AMS).

Misconceptions or misunderstandings with regard to ${ }^{14} \mathrm{C}$ dating can be technical in nature- - such as isotopic fractionation correction, calibration and the question of absolute dates, geochemical complications such as reservoir ages, single year versus multiyear samples, and wiggle-match dating. However, the worst confusion is related to perceived or real quality problems of the dating results. Both ${ }^{14} \mathrm{C}$ laboratories and archaeologists can make mistakes. The former in relation to methodology and accuracy, and the latter in relation to stratigraphic or cultural association.

\footnotetext{
${ }^{1}$ University of Groningen, Centre for Isotope Research, Nijenborgh 4, 9747 AG Groningen, The Netherlands.

Email: plicht@phys.rug.nl.

${ }^{2}$ Ben Gurion University of the Negev, Jacob Blaustein Institute for Desert Research, Sede Boker Campus 84990, Israel.

Email: hjbruins@bgumail.bgu.ac.il.
}

(C) 2001 by the Arizona Board of Regents on behalf of the University of Arizona

Near East Chronology: Archaeology and Environment. RADIOCARBON, Vol 43, Nr 3, 2001, p 1155-1166

Proceedings of the 17 th International ${ }^{14} \mathrm{C}$ Conference, edited by $\mathrm{H} \mathrm{J}$ Bruins, I Carmi, and E Boaretto 
The aim of this opening article in the special issue on Near East Chronology is threefold: 1) to advocate the necessity and potential of high-quality ${ }^{14} \mathrm{C}$ dating in Near Eastern contexts, 2) to bring some updated order in issues that often confuse non-specialist ${ }^{14} \mathrm{C}$ users, and 3) to emphasize the importance of quality control and intercomparison.

\section{${ }^{14} \mathrm{C}$ DATING, THE EGYPTIAN CALENDAR, AND NEAR EASTERN ARCHAEOLOGY}

${ }^{14} \mathrm{C}$ dating was invented in the late 1940s by WF Libby (1908-1980), who received in 1960 the Nobel Prize in Chemistry (Berger 1983). Libby (1952) used archaeological material linked with the Egyptian Calendar to verify his new method. The onset of ${ }^{14} \mathrm{C}$ dating appeared very successful. In most parts of the world archaeologists adopted ${ }^{14} \mathrm{C}$ dating as the main chronological data source. But in Near Eastern archaeology ${ }^{14} \mathrm{C}$ dating appeared too crude for cultural periods that could be associated with Egyptian and Mesopotamian historical calendars (Kenyon 1960).

${ }^{14} \mathrm{C}$ dating has improved dramatically since its inception around 1950 . In the beginning there were relatively large errors due to a lack of exact knowledge of contamination factors, corrections, and calibrations as we know today. Waterbolk (1994) noted that "the 1950s solid carbon dates are not useful due to large measurement errors induced by the earlier technology. Other early gas counting results must also be discarded". But even in the 1970s and 1980s systematic laboratory errors occurred occasionally as dates from important sites in the Near East were found too young by 200 to 300 years when compared to modern measurements (Waterbolk 1990; Bowman et al. 1990; Bruins and van der Plicht 1998). Quality control and laboratory intercomparison are, therefore, of crucial importance.

Weinstein (1984) made an important pioneering evaluation study of ${ }^{14} \mathrm{C}$ dates in the southern Levant that included both prehistoric and historic archaeological periods. He compiled a list of 474 dates and a map showing the various sites. His opening statement illustrates the common perception of ${ }^{14} \mathrm{C}$ dating in Near Eastern archaeology in the 1980s:

Radiocarbon dating provides the principal chronometric data for the Middle and Upper Palaeolithic, Epipalaeolithic, and Chalcolithic periods in the southern Levant. It is a secondary source of dating evidence for the Early Bronze Age when archaeological correlation with Syria and especially Egypt become available. For the Middle and Late Bronze age, Iron age, Persian, Hellenistic, Roman, and Byzantine periods,

${ }^{14} \mathrm{C}$ dating has only limited value because the technique is less precise than the normally available archaeologic and historic materials (Weinstein 1984:297).

Note the limited importance attributed to ${ }^{14} \mathrm{C}$ dating for Near Eastern archaeology during roughly the last 5000 years, a view essentially similar to that of Kenyon (1960) in the 1950s. Somehow, the tremendous significance of direct time measurement by ${ }^{14} \mathrm{C}$ independent of scholarly opinion was not sufficiently appreciated.

Momentous progress in ${ }^{14} \mathrm{C}$ dating was achieved by 1985 as high-precision calibration curves of the ${ }^{14} \mathrm{C}$ time scale based on dendrochronological series from different continents were presented and recommended by convention at the 12 th International ${ }^{14} \mathrm{C}$ Conference (Stuiver and Kra, editors 1986). The resulting significance was underlined by Hassan and Robinson (1987):

Radiocarbon dating began in archaeology with ancient Egypt, for it was to the securely dated materials from Egypt that Willard Libby naturally turned when his new radiocarbon method needed verification from reliable historical sources. With this paper the reverse process begins: verifying and correcting the conventional chronology for Egypt and neighbouring regions by calibrated radiocarbon" (Hassan and Robinson 1987). 
Notice the different perception about the value of ${ }^{14} \mathrm{C}$ dating in historical Near Eastern contexts as compared to Kenyon (1960) and Weinstein (1984). In fact, Hassan and Robinson consider ${ }^{14} \mathrm{C}$ dating as the primary source of time measurement ranking it above the Egyptian Calendar.

Important ${ }^{14} \mathrm{C}$ investigations concerning the Egyptian Calendar during the Old Kingdom were carried out by Haas et al (1987). Initially, 80 samples from pyramids and monuments associated with the 3rd to 6th Dynasties were collected and dated. A very significant age difference of more than 300 years was found on average between their ${ }^{14} \mathrm{C}$ dates and currently accepted scholarly assessments for the age of the above Dynasties. Their research was later expanded to a few hundred samples associated with the 1st to 12 th Dynasties, though not including every Dynasty in this range. The ${ }^{14} \mathrm{C}$ results are more complex but most samples give an older age than scholarly assessments (Bonani et al. 2001).

Egyptologists have generally been very skeptical of these ${ }^{14} \mathrm{C}$ results, often ignoring ${ }^{14} \mathrm{C}$ altogether. It is certainly not easy to give up established viewpoints in any scientific field. However, strong accumulative evidence is now emerging from ${ }^{14} \mathrm{C}$ dating. Bruins and van der Plicht (2001) show in considerable detail that ${ }^{14} \mathrm{C}$ is definitely challenging archaeo-historical time frameworks in Egypt and the southern Levant for the Early Bronze Age and the early parts of Egyptian history. High-precision dating of short-lived organic samples from Early Bronze Jericho (Bruins and van der Plicht 1998 , 2001) yielded ${ }^{14} \mathrm{C}$ results unambiguously older than Kenyon's archaeological age assessment (Kenyon 1981; Kenyon and Holland 1983). A detailed comparison and analysis of our results from Jericho through cultural archaeological linkages with ancient Egypt seems to confirm that the early parts of Egyptian history ought to be considerably older by some 100 to 300 years (Bruins and van der Plicht 2001).

A study by Braun (2001) about correlations between Early Bronze I-II sites in Israel with Proto and Early Dynastic Egypt also gives "uneasy" results as many ${ }^{14} \mathrm{C}$ dates are too old for conventional age perceptions of the early Egyptian Dynasties. Detailed ${ }^{14} \mathrm{C}$ investigations by Savage (2001) of Predynastic Egyptian ceramics also indicate that the Nagada II a/b to Nagada II b/c transition is earlier than previously estimated, which directly affects archaeological age assessment of the Early Bronze Age in the Southern Levant.

Indeed, the great importance of a high-precision calibrated ${ }^{14} \mathrm{C}$ chronology of Near Eastern archaeology (Bruins and Mook 1989) is its intrinsic independence of complex archaeological associations with historical calendars. Thus, ${ }^{14} \mathrm{C}$ dating has the potential to break through circular reasoning and built-in bias. For example, based on essentially the same archaeological and historical information different chronological opinions exist among scholars concerning archaeological associations between Egypt, the Levant, and the Aegean during the 2nd millennium BC (Bietak 1991; Dever 1992; Weinstein 1992; Manning 1995, 1999). The Iron Age chronology controversy concerning archaeological strata in Israel is another example (Balter 2000).

Surprisingly, ${ }^{14} \mathrm{C}$ dating does not seem to exist in the majority of these chronological battles, neither as an item on the agenda nor as an argument in the debate. However, a change in attitude among archaeologists towards ${ }^{14} \mathrm{C}$ dating in Egypt and the Bronze and Iron Ages of the Near East is at long last beginning to emerge as can be gauged from this volume.

The Aegean Dendrochronology Project (Kuniholm 1998; Kuniholm et al. 1996) is important for absolute dating in the Eastern Mediterranean region and the Near East. Investigations by Kuniholm on wood from Turkey, Cyprus, Greece, Crete, Lebanon, and other countries showed the utility of dendrochronology as the most precise absolute dating method in the region. Series of tree rings 
dated by both dendrochronology and ${ }^{14} \mathrm{C}$ enabled fixing the period 2687-627 $\mathrm{BC}$ (Kuniholm et al. 1996; Manning 1999). It is now possible to link suitable pieces of ancient wood found in excavations in the Eastern Mediterranean region to the Anatolian-Aegean sequence for the above time period, which is being expanded.

\section{${ }^{14}$ C DATING METHOD—CONFUSION, CONTROL, AND POTENTIAL}

BP does not mean "before publication", a statement we once encountered in a comment about one of our articles. The ${ }^{14} \mathrm{C}$ time scale is specifically defined by international convention (see e.g. Mook and Streurman 1983) and is expressed in BP, ${ }^{14} \mathrm{C}$ years "Before Present". The latter admittedly seems an unfortunate and confusing expression since "Present" corresponds here to the standard year $1950 \mathrm{AD}$. But such a definition is needed because of the natural variations in the atmospheric ${ }^{14} \mathrm{C}$ content, which cause the ${ }^{14} \mathrm{C}$ clock to run at a different (and varying) pace in comparison with the astronomical clock.

The relation between the ${ }^{14} \mathrm{C}$ time scale and real calendar time can be obtained by means of calibration: dating of samples by both ${ }^{14} \mathrm{C}$ and another, independent method. Dendrochronology is most suitable as this method gives truly absolute dates. Through ${ }^{14} \mathrm{C}$ analysis of wood from tree rings dated by dendrochronology one can establish the relationship between the two time scales. The most recent recommended calibration curve is called INTCAL98 (Stuiver and van der Plicht, editors 1998). This curve is decadal, i.e. has a resolution of 10 calendar years. Figure 1 shows the segment $3500-0$ BC of the calibration curve relevant for Near-Eastern Archaeology. The ${ }^{14} \mathrm{C}$ wiggles are clearly visible as real changes in the past atmospheric ${ }^{14} \mathrm{C}$ content that complicates the calibration process. Calibrated age in astronomical calendar years are expressed as years $c a l B C$ or $c a l A D$ by convention (Mook 1986).

Calibration of ${ }^{14} \mathrm{C}$ dates should be carried out by advanced computer programs (Stuiver and Reimer 1993; Bronk Ramsey 1995, 1998, 2000; van der Plicht 1993), updated with the INTCAL98 dataset.

The ${ }^{14} \mathrm{C}$ dating method is based on the measurement of the concentration or the decay rate of the radioactive isotope ${ }^{14} \mathrm{C} .{ }^{14} \mathrm{C}$ is present in organic matter derived from plants or animals, albeit in extremely small quantities. ${ }^{14} \mathrm{C}$ dating is the main scientific method for chronological measurements during the last 50,000 yr. At least a few grams of carbon are needed to measure the radioactivity of organic material, now called the conventional ${ }^{14} \mathrm{C}$ method (see e.g. Kromer and Münnich 1992; Theodórsson 1996).

Since the 1980s it became possible to measure the ${ }^{14} \mathrm{C}$ concentration directly by means of AMS. The AMS method only requires a milligram of carbon, significantly expanding the range of ${ }^{14} \mathrm{C}$ applications (Hedges and Gowlett 1986; Elmore and Phillips 1987; Tuniz et al. 1998).

There are at present some 120 conventional ${ }^{14} \mathrm{C}$ laboratories and 20 AMS facilities (see list of laboratories in Radiocarbon 39(3):361-86; see also listing at http://www.radiocarbon.org), located in various parts of the world. Many of these laboratories have a routine annual sample throughput of about 1000 samples. The applications of ${ }^{14} \mathrm{C}$ are wide-ranging: dating (archaeology, geology, hydrology), carbon cycle research (atmospheric trace gases, ocean sciences, soil sciences), and others such as biomedical research (Taylor et al. 1992).

The intrinsic nature of radioactive decay causes the results of repeated measurements to spread around a "true" value. "The possible discrepancy between a measured value and the "true" value is indicated by the standard deviation ( $\sigma$ )" (Mook and Waterbolk 1985). The standard deviation in the Physical Sciences commonly corresponds to $1 \sigma\left(68 \%\right.$ probability). ${ }^{14} \mathrm{C}$ laboratories produce ages with uncer- 


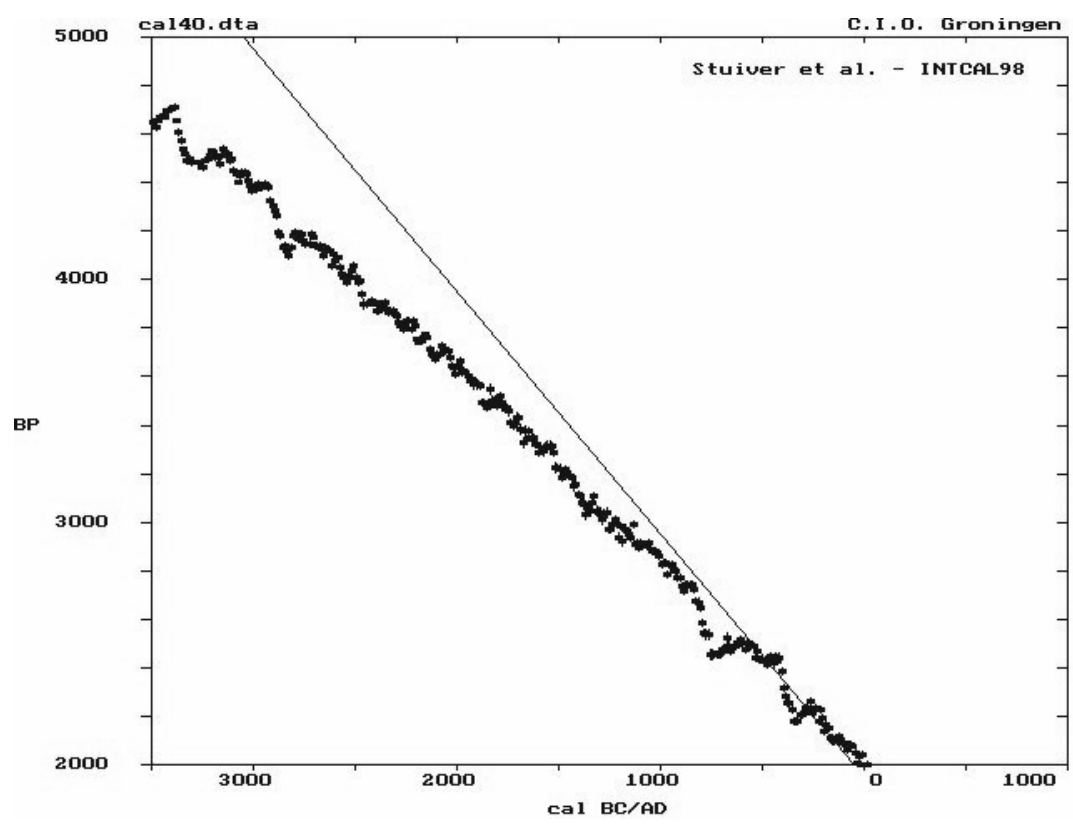

Figure 1 Part of the calibration curve INTCAL98 for ${ }^{14} \mathrm{C}$ dating (Stuiver et al. 1998) obtained from dendrochronologically dated wood. The ${ }^{14} \mathrm{C}$ measurements are plotted in $\mathrm{BP}$ along the vertical axis, the horizontal axis represents the dendrochronological time-scale (cal BC/AD). The straight line would indicate a constant atmospheric ${ }^{14} \mathrm{C}$ content through time. The figure is generated by the Groningen Radiocarbon Calibration Program (van der Plicht 1993)

tainties of about $0.5 \%$, i.e. a few decades for most archaeological samples. More precise measurements (down to $0.2 \%$ ) are called "high-precision measurements". These can only be achieved under certain conditions, including a sufficiently large amount of datable material (conventional laboratories), a low background, and the "quality" of the ${ }^{14} \mathrm{C}$ laboratory (Mook and Waterbolk 1985).

Our series of Middle Bronze Age II ${ }^{14} \mathrm{C}$ dates for Tell es-Sultan (ancient Jericho) is an example of a reliable set of high-precision ${ }^{14} \mathrm{C}$ measurements. Short-lived botanical remains from stratified layers were dated at the Groningen Conventional Laboratory. Enough material (50 g of charred seeds) was available for measurement in the large $(25 \mathrm{~L})$ counter. Gauging the radioactivity from a sample for about 4 days in this counter-in addition to the appropriate standard and background measurements - yields a precise date with a standard deviation down to about 15 BP (Bruins and van der Plicht 1995, 1996, 1998).

True point dates cannot be achieved with ${ }^{14} \mathrm{C}$ dating as there always is a standard deviation. Another limitation is the shape of the calibration curve that can cause even very precise BP dates to get a rather wide age range in historical years (e.g. Bruins and van der Plicht 1995, 1996, 1998; Manning 1999). Less precise BP dates, on the other hand, would render an even wider calibrated date. Hence, the quality of the $\mathrm{BP}$ date always forms the basis for every ${ }^{14} \mathrm{C}$ age determination. Comparative analysis between dates within the ${ }^{14} \mathrm{C}$ time scale remains important (Bruins and van der Plicht 1996), which may have become overlooked in the quest for calibration.

Despite these inherent limitations it must be realized that a ${ }^{14} \mathrm{C}$ date does provide a universal physical measurement of time, independent of cultural-historical viewpoints and associative reasoning. 
Such information is of irreplaceable value as both an independent and unifying data set in a variety of disciplines, i.e. archaeology, geology, soils, paleoclimatic, and environmental studies.

More detailed information on ${ }^{14} \mathrm{C}$ dating - principles of the method, measuring techniques, etc. can be found in textbooks, i.e. Tuniz et al. (1998), Taylor and Aitken (1997), Aitken (1990), Geyh and Schleicher (1990), Mook and Waterbolk (1985), Mook and Streurman (1983), Libby (1981), as well as via the website of the journal Radiocarbon: http://www.radiocarbon.org.

\section{SAMPLES}

Sample selection is a critical component in the ${ }^{14} \mathrm{C}$ dating process. The layers from which archaeological or geological samples are taken during excavations have not always remained static and may have been affected by different kinds of post-depositional processes. For example, perturbation by plants and animals, soil carbonate movement or human activities (e.g. digging) may cause migration or contamination of carbon in samples used for ${ }^{14} \mathrm{C}$ dating.

Another key question is the relationship between the age of the sample and the archaeological or historical question addressed: "how is the ${ }^{14} \mathrm{C}$ event related to the human event to be dated" (Van Strydonck et al. 2000). A well-known problem in this respect is the so-called "old wood effect": cedar or oak wood used (or re-used) to construct a building may have a ${ }^{14} \mathrm{C}$ date that differs from the human construction event by several centuries. It must be emphasized that the ${ }^{14} \mathrm{C}$ date in such a case is NOT a measurement mistake. Rather, the age of the wood sample is older than the age of the archaeological layer or building in which it was found.

Samples of organisms living in carbon reservoirs different from the atmosphere (such as marine and fluviatile environments) can have deviating ${ }^{14} \mathrm{C}$ dates resulting from so-called "reservoir effects" (Stuiver et al. 1998; Olsson 1983).

Another important matter related to sample selection is the respective choice of "conventional dating versus AMS". There can be a temptation to collect and submit isolated flecks of charcoal. The dating of such samples by AMS should be discouraged. If sufficient material is available, samples can be dated more cheaply and often more accurately by conventional means. The possibility of dating erratic post-depositional influences is considerable when isolated small fragments of charcoal or seeds are used, which are liable to movement by faunal or human digging activity. Such tiny samples have to be derived from a clearly defined context or association to justify dating. For a more detailed discussion with examples, see Lanting and van der Plicht (1994). It is a "myth" that AMS is better than conventional ${ }^{14} \mathrm{C}$ dating: standard deviations are not smaller.

Finally, time width effects represented by a sample have to be considered. Bulk samples of peat layers, for example, are centimeters thick for conventional ${ }^{14} \mathrm{C}$ analysis. Such a sample comprises many years of sedimentation or growth. Isolated seeds, macrofossils, and grains represent single year samples and are typical AMS material due to their small sample size, but the stratigraphic context must be clear, as noted above. The correct calibration procedure of ${ }^{14} \mathrm{C}$ dates from multi year or single year samples needs to be considered. Smoothed curves are recommended for multi year samples, while single year samples ought to be calibrated with the most detailed calibration curve available (Mook and Waterbolk 1985).

For all ${ }^{14} \mathrm{C}$-measurement techniques, $\mathrm{CO}_{2}$ has to be prepared from a wide variety of organic materials such as wood, bone, charcoal, peat, textile, carbonates, etc. The carbon must be representative of the material to be dated. Obviously, carbon from other sources signifies contamination and has to be removed. Pretreatment depends strongly on factors such as the kind of sample, the quality of the 
sample, and the quantity of material. More specific details on pretreatment can be found in the technical treatise by Mook and Streurman (1983). Following pretreatment, the extracted datable fraction of the sample is combusted to $\mathrm{CO}_{2}$.

Contamination includes any carbon that is foreign to the sample material. Contamination may occur in nature, in the field, and in the laboratory. Depending on the source of the foreign carbon, sample dates can be made younger or older. We present here only a short survey of most common contamination problems encountered.

Natural sources of contamination are fossil organic matter, fossil carbonate, humic infiltration, root penetration, secondary carbonates, and biological admixture by animal activity. Fossil carbon does not contain a measurable amount of ${ }^{14} \mathrm{C}$ (is older than 50,000 yr). Such contamination makes the sample older than its real age. On the other hand, penetrating plant roots, if not removed, cause samples to become younger than their real age. Human handling can also contaminate samples: admixture during collection, packing materials, and preservatives. Most notorious are preservatives used for bone collections, quite often collagen glue. However, the datable fraction to be extracted from the bone is also collagen! Preservatives can be fossil $\left({ }^{14} \mathrm{C}\right.$ free, modern industrial, or synthetic origin) or contemporaneous with the time of preservation (natural origin, for example medieval glue).

Short-lived samples are always of key importance in ${ }^{14} \mathrm{C}$ dating, but dates on multi year charcoal remain important and should not be dismissed. Seeds such as cereal grains and olive pits often constitute excellent short-lived material. However, bones too are usually short-lived and may be dated successfully. A breakthrough has recently been accomplished in the dating of cremated bones (Lanting et al 2001). Cremated means that the bones were exposed to temperatures above $600{ }^{\circ} \mathrm{C}$, causing bioapatite to recrystallize. This structural carbonate appears to be datable with a high rate of success (see Lanting et al 2001 for a report on an extensive testing program). Note that charred or burnt bones that were exposed to lower temperatures usually around $300^{\circ} \mathrm{C}$ remain problematic for dating purposes.

\section{QUALITY CONTROL AND INTERCOMPARISON IN NEAR EASTERN CONTEXTS.}

The ${ }^{14} \mathrm{C}$ community has a long tradition of standardization and intercomparison:

All ${ }^{14} \mathrm{C}$ measurements are relative to a standard. This standard is oxalic acid, distributed by NIST (formerly NBS) and defined as corresponding with $1950 \mathrm{AD}$. The standard is independent of the measurement technique-conventional (counters and scintillation) and AMS. Of course, there are complications, as the original standard became exhausted and had to be replaced by a new batch of oxalic acid. In addition, there are fractionation corrections, etc. For a full treatise we refer to the specialized literature (e.g. Mook and van der Plicht 1999).

Working standards exist with different ${ }^{14} \mathrm{C}$ concentrations, such as the series $\mathrm{C} 1-\mathrm{C} 8$ distributed by the International Atomic Energy Agency (IAEA, Rozanski et al. 1992; Le Clercq et al. 1998). C1 is marble of infinite age, C2 is chalk with an age of $7135 \mathrm{BP}, \mathrm{C} 3$ is modern (129.41\%) paper, C4 is wood (>43,500 BP), C5 is wood (11,790 BP), C6 is modern (150.61\%) sucrose, C7 and C8 are oxalic acid mixtures (5645 BP and 15,225 BP, respectively).

Laboratories active in ${ }^{14} \mathrm{C}$ dating of dendrochronological series for calibration of the ${ }^{14} \mathrm{C}$ timescale often exchange tree ring dated wood for cross checking the reliability of their results (Kromer et al. 1996). These are usually quality laboratories capable of high precision measurements. 
Intercomparison exercises of unknown samples are periodically organized. These include sample treatment effects, measurement techniques, backgrounds, and samples for the complete dating range.

Currently, a Fourth International Radiocarbon Intercomparison (FIRI) exercise is running with the following aims:

- evaluation of the comparability of routine analysis of both AMS and conventional laboratories;

- quantification of the extent of and the sources for any variation; and

- investigation of the effects of sample size, precision, and pretreatment on the results (Bryant et al. 2000, 2001).

Laboratory quality assurance has a number of components, including the use of in-house reference materials, measurement of international standards, provision for detailed sample, procedural documentation, and regular participation in laboratory inter-comparisons. The outcome of FIRI will provide a detailed quantification of the uncertainties associated with ${ }^{14} \mathrm{C}$ measurements, including the issues of accuracy and precision. Past intercomparison reports can be found in Scott et al. (1990), Rozanski et al. (1992), and Gulliksen and Scott (1995).

The significance of quality control and laboratory intercomparison in relation to Near Eastern archaeology became clear from the investigation by Bruins and van der Plicht (1998) concerning Early Bronze Jericho. Some EB strata excavated by the late Dame Kathleen Kenyon were dated during the early 1970s in the British Museum ${ }^{14} \mathrm{C}$ laboratory (Burleigh 1981). Our high-precision ${ }^{14} \mathrm{C}$ dates on short-lived samples, partly derived from the same strata, were carried out during the 1990s in the Groningen Radiocarbon laboratory. The results showed that the BM dates were systematically about 300 years too young on the ${ }^{14} \mathrm{C}$ time scale. An earlier comparative study by Waterbolk (1990) of Near Eastern ${ }^{14} \mathrm{C}$ dates had already shown that BM dates tended to be on the younger side as compared to other ${ }^{14} \mathrm{C}$ labs. It was also found that BM dates issued during the period 1980-1984 were on average $200-300{ }^{14} \mathrm{C}$ years too young (Bowman et al. 1990).

It is clear that occasionally a ${ }^{14} \mathrm{C}$ laboratory may inadvertently produce erroneous ${ }^{14} \mathrm{C}$ dates. The formation of a high quality ${ }^{14} \mathrm{C}$ chronology of Near Eastern archaeology of the Bronze and Iron Ages, including the verification and possible time fixation of elements in the Egyptian Calendar requires thorough quality control through ongoing laboratory intercomparison. One possibility is that important uniform samples that are sufficiently large in size—e.g. grains from a silo-should be split for duplicate, or even triplicate conventional analysis, and likewise AMS for smaller samples.

Duplicate measurements of samples may already give confirmation of the result and hence ensure quality control. But it may also lead to different results. Waterbolk (1990:148) stated: "If a sample has been measured twice, be it by the same or by an other laboratory, and the results are not congruent, we cannot know which date to reject". In such cases a third measurement on the same sample should be conducted in order to determine the correct ${ }^{14} \mathrm{C}$ date. Obviously, this will raise the costs.

In addition, it may be advisable to have some samples dated as a duplicate or triplicate at a known "high quality" laboratory, be it conventional or AMS. However, archaeologists should discuss such important quality control strategies in a transparent way with the ${ }^{14} \mathrm{C}$ labs involved. Sometimes samples are not uniform and also may not be divided correctly in duplo or triplo. Different dating results may then be wrongly blamed on the ${ }^{14} \mathrm{C}$ labs, while in fact sample non-uniformity and erroneous sample splitting may have been the cause. 


\section{DATING PRECISION}

The standard deviation $\sigma$ of the ${ }^{14} \mathrm{C}$ date is usually based on the uncertainty in the ${ }^{14} \mathrm{C}$ counts for sample, standard, and background. A measure of the reproducibility of the result is another very important factor that influences the standard deviation. Reproducibility is generally estimated by using in-house standards (known age material) and may often be negligible. However, this factor is nevertheless crucial in quality control. Laboratories may be tempted to report a small standard deviation based on radiometry counting only, but neglecting the reproducibility of the date. The latter may also be related to other factors in standard lab routine and performance, including the quality of equipment, etc.

The measured result in conventional ${ }^{14} \mathrm{C}$ years reported in $\mathrm{BP}$ with $1 \sigma$ standard deviation assigned corresponds to a relatively simple mathematical concept: a Gaussian probability distribution. After calibration a ${ }^{14} \mathrm{C}$ date is usually not Gaussian but much more complex due to the presence of wiggles. The calibrated probability distribution that represents the real age of the sample may result from several intersects of the BP date with the calibration curve. Hence the calibrated date may be bimodal or even have three or more possibilities (Bruins and van der Plicht 2001). The calibrated result may also be very imprecise due to a plateau in the calibration curve as occurs between 800 $400 \mathrm{cal} \mathrm{BC}$ (see Figure 1). Computer programs are best suited to calculate calibrated ${ }^{14} \mathrm{C}$ dates in view of the complexities involved.

The calibrated age range is not only defined by counting statistics, but is also "wiggle" dependent. The calibrated age range for a series of dates can be narrowed down by "wiggle matching" (Pearson 1986) or using special statistics (Bronk Ramsey 1998). "High precision" measurements are usually defined as those with errors $<0.2 \%$. For very large samples containing more than 10 grams of $\mathrm{C}$ and measured with proportional gas counting, the smallest feasible limit of $\sigma$ is more or less 15 BP. This lower limit of $\sigma$ precision results from the following constraints:

- the error margins of standards and backgrounds are of the same order; and

- the error margins of the calibration curve are not smaller as the ${ }^{14} \mathrm{C}$ measurements of the dendro-dated wood are "high precision" by themselves. The INTCAL98 curve is decadal (i.e. one datapoint per 10 tree rings representing 10 calendar years).

Nevertheless, the smaller the $\sigma$ of the original ${ }^{14} \mathrm{C}$ BP date, the more precise the calibrated result in $\mathrm{cal} \mathrm{BC}$ or cal AD. Conventional counting methods are able to give a smaller standard deviation than AMS measurements. Samples for high precision dating consist of sizable quantities of short-lived organic material, such as cereals and other seeds. Bones can also be a very useful short-lived material, as even cremated bones can now be dated successfully (Lanting et al. 2001). Young wood (small twigs or branches) are also likely to be rather short-lived. Multi year charcoal is often older, though not necessarily by a large margin (Bruins and van der Plicht 1995).

Combined stratified series of short-lived samples and multi year charcoal are better than only a few isolated short-lived dates. A paramount requirement for the establishment of a high-quality ${ }^{14} \mathrm{C}$ chronology of Near Eastern archaeology involves the ${ }^{14} \mathrm{C}$ data acquisition of as many archaeological layers as possible. Short-lived samples are unfortunately not available from every layer, so many dating gaps would occur in a stratified series. Therefore, only the combination of multi year charcoal and short-lived samples can provide a more complete series of dates. The number of stratified dates is important, as it provides for internal consistency and quality control, contributing to the reliability of the respective values of the short-lived dates (Bruins et al., in preparation). 
The calibration wiggles can become an opportunity for accurate and precise dating in the order of decades if seriated series of many stratified ${ }^{14} \mathrm{C}$ dates are measured from archaeological sites. Simultaneous multi phase calibration may be possible to fit the stratigraphic sequence of ${ }^{14} \mathrm{C}$ dates on the calibration curve, i.e. archaeological wiggle matching (Weninger 1992, 1995; Manning and Weninger 1992). If insufficient seriated dates are available for wiggle matching, it is still possible to narrow down the individual calibrated age ranges through statistical techniques provided in the OxCal program (Bronk Ramsey 2000).

Moreover, pieces of ancient wood that cannot be related to the Anatolian-Aegean dendrochronological sequence (Kuniholm et al 1996), due to age or tree species, may be "wiggle-matched" to the ${ }^{14} \mathrm{C}$ calibration curve. Slices of ten tree rings must be dated individually and the seriated sequence of dates may be matched to the 1998 master ${ }^{14} \mathrm{C}$ curve, provided the sequence is long enough.

\section{CONCLUSION AND RECOMMENDATIONS}

${ }^{14} \mathrm{C}$ dating in the Near East and Eastern Mediterranean has entered a crucial verification and correction phase of archaeo-historical chronologies. There is now increasing ${ }^{14} \mathrm{C}$ evidence that the early part of Egyptian history seems older than currently assumed on the basis of scholarly reasoning. Time ought to be measured by physical dating methods, ${ }^{14} \mathrm{C}$, and dendrochronology as a standard procedure. Complex archaeological age assessments based on cultural definitions and foreign synchronisms have their own value, but the inherent danger of circular reasoning must be recognized.

${ }^{14} \mathrm{C}$ dating does have its limitations, particularly, the rather wide age ranges that often result after calibration due to the irregular shape of the calibration curve. Nevertheless, ${ }^{14} \mathrm{C}$ dating is irreplaceable as a time measurement independent of archaeological age assessment and historical estimates. Charred bones can now be dated accurately by ${ }^{14} \mathrm{C}$, while the fact that bones are usually short-lived adds great significance and quality to their dating.

Statistical evaluation of data series is important for the establishment of a high-quality ${ }^{14} \mathrm{C}$ chronology of Near Eastern Archaeology. Sophisticated calibration procedures with sequence analysis based on site stratigraphy and seriation may be possible, and sometimes even archaeological wiggle matching. In fact, the wiggles in the calibration curve may become an advantage with high stratigraphic and ${ }^{14} \mathrm{C}$ data resolution that may enable very accurate and precise dating.

Data compilation and comparative analysis of large time series from many sites is of great significance. However, such analyses must include a quality evaluation of the dates in relation to the respective ${ }^{14} \mathrm{C}$ laboratories.

Reproducibility of a ${ }^{14} \mathrm{C}$ measurement on the same sample is both a check and confirmation of accuracy and reliability. It is, therefore, important that key samples are measured to the highest possible precision, i.e. the samples are short-lived, large in size, and preferably subject to duplicate or triplicate analysis. If two measurements are carried out on material from the same sample, either at the same laboratory or at two different ${ }^{14} \mathrm{C}$ labs and the results are dissimilar, then a third analysis is required to establish the correct date assuming that by now at least two dates will be similar.

A joint effort should be made to capture the past flow of time and events in relation to the great civilizations of the Old World as reliably as possible with ${ }^{14} \mathrm{C}$. Dendrochronology and wiggle matching of stratified ${ }^{14} \mathrm{C}$ series may enable greater precision where possible and applicable. 


\section{ACKNOWLEDGMENTS}

The detailed comments by Dr Jan Lanting (Biological-Archaeological Institute, University of Groningen) on an earlier draft are greatly appreciated.

\section{REFERENCES}

Aitken MJ. 1990. Science-based dating in archaeology. London and New York: Longman.

Balter M. 2000. The Two Tels: Armageddon for biblical Archaeology? Science 287:31-2.

Berger R. 1983. Willard Frank Libby, 1908-1980. PACT 8:13-16.

Bietak M. 1991. Egypt and Canaan during the Middle Bronze Age. Bulletin of the American Schools of Oriental Research 281:27-72.

Bonani G, Haas H, Hawass Z, Lehner M, Nakhla S, Nolan J, Wenke R, Wölfli W. 2001. Radiocarbon Dates of Old and Middle Kingdom Monuments in Egypt. Radiocarbon 43(3). This issue.

Bowman SGE, Ambers JC, Leese MN. 1990. Re-evaluation of British Museum radiocarbon dates issued between 1980 and 1984. Radiocarbon 32(1):59-79.

Braun E. 2001. Proto and Early Dynastic Egypt and Early Bronze I-II of the Southern Levant: some uneasy ${ }^{14} \mathrm{C}$ correlations. Radiocarbon 43(3). This issue.

Bronk Ramsey C. 1995. Radiocarbon calibration and analysis of stratigraphy: the OxCal program. Radiocarbon 37(1): 425-30.

Bronk Ramsey C. 1998. Probability and dating. Radiocarbon 40(1):461-74.

Bronk Ramsey C. 2000. OxCal Program version 3.5. Radiocarbon Accelerator Unit, University of Oxford. http://www.rlaha.ox.ac.uk/oxcal.

Bruins HJ, Mook WG. 1989. The need for a calibrated radiocarbon chronology of Near Eastern archaeology. Radiocarbon 31(3):1019-29.

Bruins HJ, van der Plicht J. 1995. Tell Es-Sultan (Jericho): Radiocarbon results of short-lived cereal and multiyear charcoal samples from the end of the Middle Bronze Age. Radiocarbon 37(1):213-20.

Bruins HJ, van der Plicht J. 1996. The Exodus enigma. Nature 382:213-14.

Bruins HJ, van der Plicht J. 1998. Early Bronze Jericho: High precision ${ }^{14} \mathrm{C}$ dates of short-lived palaeobotanic remains. Radiocarbon 40(2):621-28.

Bruins HJ, van der Plicht J. 2001. Radiocarbon challenges archaeo-historical time frameworks in the Near East: the Early Bronze Age of Jericho in relation to Egypt. Radiocarbon 43(3). This issue.

Bryant C, Carmi I, Cook G, Gulliksen S, Harkness D, Heinemeijer J, McGee E, Naysmith P, Possnert G, Scott M, van der Plicht J, van Strydonck M. 2000. Sample requirements and design of a inter-laboratory trial for radiocarbon laboratories. AMS-8 conference, Vienna, 6-10 September 1999. Nuclear Instruments and Methods in Physics Research B172:355-58.
Bryant C, Carmi I, Cook G, Gulliksen S, Harkness D, Heinemeijer J, McGee E, Naysmith P, Possnert G, Scott M, van der Plicht J, van Strydonck M. 2001. Is comparability of ${ }^{14} \mathrm{C}$ dates an issue? Radiocarbon 43(2).

Burleigh R. 1981. Radiocarbon dates. In: Kenyon KM, Holland TA, editors. Excavations at Jericho. Volume 3. The Architecture and Stratigraphy of the Tell. Appendix C. London: The British School of Archaeology in Jerusalem. 501-4.

Dever WG. 1992. The chronology of Syria-Palestine in the second millennium BCE: A review of current issues. Bulletin of the American Schools of Oriental Research 288:1-25.

Elmore D, Phillips FM. 1987. Accelerator Mass Spectrometry for measurement of long-lived radioisotopes. Science 236: 543-50.

Geyh MA, Schleicher H. 1990. Absolute age determination. Physical and chemical dating methods and their application. (English by RC Newcomb). Berlin/ Heidelberg: Springer Verlag.

Gulliksen S, Scott EM. 1995. TIRI report. Radiocarbon 37(2):820-21.

Haas H, Devine J, Wenke R, Lehner M, Woelfli W, Bonani G. 1987. Radiocarbon chronology and the historical calendar in Egypt. In: Aurenche O, Evin J, Hours F, editors. Chronologies in the Near East. Oxford: BAR International Series 379: 585-606.

Hassan FA, Robinson SW. 1987. High-precision radiocarbon chronometry of ancient Egypt and comparisons with Nubia, Palestine and Mesopotamia. Antiquity 61:119-35.

Hedges REM, Gowlett JAJ. 1986. Radiocarbon dating by Accelerator Mass Spectrometry. Scientific American 254:100-7.

Kenyon KM. 1960. Archaeology in the Holy Land. London: Ernest Benn, Ltd. 326 p.

Kenyon KM. 1981. Holland TA, editor. Excavations at Jericho. Volume 3. The Architecture and Stratigraphy of the Tell. London: The British School of Archaeology in Jerusalem.

Kenyon KM, Holland TA. 1983. Excavations at Jericho. Volume 5. The Pottery Phases of the Tell and Other Finds. London: The British School of Archaeology in Jerusalem.

Kromer B, Münnich KO. 1992. $\mathrm{CO}_{2}$ gas proportional counting in radiocarbon dating-review and perspective. In: Taylor RE, Long A, Kra RS, editors. Radiocarbon after four decades. An interdisciplinary perspective. New York: Springer Verlag. p 184-97. 
Kromer B, Ambers J, Baillie MGL, Damon PE, Hesshaimer V, Hofmann J, Jöris O, Levin I, Manning SW, McCormac FG, van der Plicht J, Spurk M, Stuiver M, Weninger B. 1996. Report: Summary of the workshop "Aspects of high-precision radiocarbon calibration.” Radiocarbon 38(3):607-10.

Kuniholm PI. 1998. Aegean Dendrochronology Project, progress report, http://www.arts.cornell.edu/dendro.

Kuniholm PI, Kromer B, Manning SW, Newton M, Latini CE, Bruce MJ. 1996. Anatolian tree rings and the absolute chronology of the Eastern Mediterranean 2220-718 BC. Nature 381:780-83.

Lanting JN, van der Plicht J. 1994. ${ }^{14} \mathrm{C}-\mathrm{AMS}$ : pros and cons for archaeology. Palaeohistoria 35/36:1-12.

Lanting JN, Aerts AT, van der Plicht J. 2001. Dating of cremated bones. Radiocarbon 43(2).

Le Clercq M, van der Plicht J, Gröning M. 1998. New ${ }^{14} \mathrm{C}$ reference materials with activities of 15 and $50 \mathrm{pMC}$. Radiocarbon 40(1):295-7.

Libby WF. 1952 (re-issued in 1965). Radiocarbon dating. Chicago: Chicago University Press.

Libby WF. 1981. Tritium and radiocarbon. Berger R, Libby LM, editors. Santa Monica: Geo Science Analytical. (Collected Papers, Libby WF, volume 1).

Manning SW. 1995. The absolute chronology of the Aegean Early Bronze Age: archaeology, history, and radiocarbon. Sheffield: Sheffield Academic Press.

Manning SW. 1999. A test of time: the volcano of Thera and the chronology and history of the Aegean and Eastern Mediterranean in the mid second millennium $B C$. Oxford: Oxbow Books.

Manning SW, Weninger B. 1992. A light in the dark: archaeological wiggle matching and the absolute chronology of the close of the Aegean Late Bronze Age. Antiquity 66:636-63.

Mook WG. 1986. Business meeting, 12th International Radiocarbon Conference. Radiocarbon 28(2A):799.

Mook WG, Streurman HJ. 1983. Physical and chemical aspects of radiocarbon dating. In: Mook WG, Waterbolk HT, editors. Proceedings, Groningen Symposium ${ }^{14} \mathrm{C}$ and Archaeology. PACT 8:31-55.

Mook WG, van der Plicht J. 1999. Reporting ${ }^{14} \mathrm{C}$ activities and concentrations. Radiocarbon 41(3):227-39.

Mook WG, Waterbolk HT. 1985. Handbook for archaeologists, no. 3. radiocarbon dating. Strasbourg: European Science Foundation.

Olsson IU. 1983. Dating non-terrestrial materials. PACT 8:277-94.

Pearson GW. 1986. Precise calendrical dating of known growth-period samples using a 'curve fitting' technique. Radiocarbon 28(2A):292-9.

Rozanski K, Stichler W, Gonfiantini R, Scott EM, Beukens RP, Kromer B, van der Plicht J. 1992. The IAEA ${ }^{14} \mathrm{C}$ intercomparison exercise. Radiocarbon 34(3): 506-19.

Savage SH. 2001. Toward an AMS radiocarbon chronology of Predynastic Egyptian ceramics. Radiocarbon 43(3). This issue.
Scott EM, Aitchison TC, Harkness DD, Cook GT, Baxter MS. 1990. An overview of all three stages of the international radiocarbon intercomparison. Radiocarbon 32(3):309-19.

Stuiver M, Kra RS, editors. 1986. Calibration Issue. Radiocarbon 28(2B).

Stuiver M, Reimer PJ, Braziunas TF. 1998. High-precision radiocarbon age calibration for terrestrial and marine samples. Radiocarbon 40(3):1127-51.

Stuiver M, van der Plicht J, editors. 1998. INTCAL98, Calibration Issue, Radiocarbon 40(3).

Stuiver M, Reimer PJ. 1993. Extended ${ }^{14} \mathrm{C}$ database and revised CALIB $3.0{ }^{14} \mathrm{C}$ age calibration program. $R a$ diocarbon 35(1):215-30.

Stuiver M, Reimer PJ, Bard E, Beck JW, Burr GS, Hughen KA, Kromer B, McCormac G, van der Plicht J, Spurk M. 1998. INTCAL98 radiocarbon age calibration 24,000-0 cal BP. Radiocarbon 40(3):104184.

Taylor RE, Aitken MJ, editors. 1997. Chronometric dating in archaeology. Advances in archaeological and museum science. Vol. 2. New York: Plenum Press.

Taylor RE, Long A, Kra RS, editors. 1992. Radiocarbon after four decades. An interdisciplinary perspective. New York: Springer Verlag.

Theodórsson P. 1996. Measurement of weak radioactivity. Singapore: World Scientific Publishing Co. Ltd.

Tuniz C, Bird JR, Fink D, Herzog GF. 1998. Accelerator mass spectrometry. Washington D.C.: CRC Press.

van der Plicht J. 1993. The Groningen Radiocarbon Calibration Program. Radiocarbon Calibration issue. $R a$ diocarbon 35(1):231-7.

Van Strydonck M, Nelson DE, Crombé P, Bronk Ramsey C, Scott EM, van der Plicht J, Hedges REM. 2000. What's in a ${ }^{14} \mathrm{C}$ date. Proceedings of the $3 r d$ International Symposium on ${ }^{14} \mathrm{C}$ and Archaeology. Lyon, France. 6-10 April 1998. p 433-40.

Waterbolk HT. 1990. Quality differences between radiocarbon laboratories illustrated on material from SW Asia and Egypt. In: Mook WG, Waterbolk HT, editors. Proceedings of the Second International Symposium, ${ }^{14} \mathrm{C}$ and Archaeology, Groningen 1987. PACT 29:14158.

Waterbolk HT. 1994. Radiocarbon dating Levantine prehistory. In: Bar-Yosef O, Kra RS, editors. Late Quaternary chronology and paleoclimates of the Eastern Mediterranean. Tucson: Radiocarbon.

Weinstein JM. 1984. Radiocarbon dating in the Southern Levant. Radiocarbon 26(3):297-366.

Weinstein JM. 1992. The chronology of Palestine in the early second millennium BCE. Bulletin of the American Schools of Oriental Research 288:27-46.

Weninger B. 1992. Fallstudien zur ${ }^{14} \mathrm{C}$ chronologie in Bulgarien, Sofia. Studia Praehistoria 11-12:407-25.

Weninger B. 1995. Stratified ${ }^{14} \mathrm{C}$ dates and ceramic chronologies: case studies for the Early Bronze Age at Troy (Turkey) and Ezero (Bulgaria). Radiocarbon 37(2):443-56. 